\title{
FAVIPIRAVIR AND DEXAMETHASONE IN MANAGEMENT OF SARS-COV2 INFECTION (PILOT STUDY)
}

\author{
M. Latief', O. Shafi' ${ }^{2}$, Z. Hassan ${ }^{3}$, *F. Abbas ${ }^{4}$ \\ 1 - GANDHI MEDICAL COLLEGE AND HOSPITAL, HYDERABAD, INDIA \\ 2 - FLUSHING HOSPITAL MEDICAL CENTER NEW YORK, USA \\ 3 - GOVERNMENT MEDICAL COLLEGE, BARAMULLA, INDIA \\ 4 - PATHOLOGY DIVISION GOVERNMENT MEDICAL COLLEGE, SRINAGAR, INDIA
}

Background. The clinical presentation of Coronavirus disease 19 (COVID-19) varies from mild symptoms to severe illness including multiorgan dysfunction. Favipiravir is an antiviral agent which has been previously used for treatment of influenza and was recently approved for treatment of mild to moderate COVID-19 in India.

Objective. The Objective of this study was to assess the role of Favipiravir and Dexamethasone in patients with COVID-19.

Methods. A total of 17 patients were included in this observational study. The included patients were RT-PCR for SARS-Cov-2 positive with increased inflammatory markers. All patients received Antiviral therapy, Anticoagulation (Enoxaparin 0.4mg subcutaneous twice daily), Steroids (Dexamethasone $8 \mathrm{mg}$ daily for 5 days and $4 \mathrm{mg}$ daily for 5 days). Viral clearance (time to RT-PCR negative), time to defervescence after antiviral therapy, time to become independent of Oxygen support was studied.

Results. Fever, myalgias, dry cough and dyspnea were the commonest presentation of COVID-19. All of our patients had lymphopenia. In our study 11 (64.7\%) patients had bilateral ground glass opacities on CT chest while 6 had consolidation in addition to ground glass opacities. In two patients, who required non-invasive ventilation, Favipiravir was stopped and these patients received Remdesivir for a total of 5 days. In patients who received Favipiravir only, the Median time to RT-PCR negative, defervescence and oxygen independence was 8,3 and 6 days respectively.

Conclusion. Our observational study demonstrated improvement in the majority of patients with COVID-19 with use of Favipiravir. Additional studies are needed to compare the efficiency of Favipiravir with Remdesivir.

KEYWORDS: SARS-CoV-2; Favipiravir; Remdesivir; COVID-19.

\section{Introduction}

COVID-19 or coronavirus disease 2019, is a novel illness caused by recently discovered severe acute respiratory syndrome coronavirus 2 (SARS-CoV-2). The virus was first identified in Wuhan, a city in the Hubei province of China in December 2019 and has since rapidly spread into a global pandemic causing considerable morbidity and mortality worldwide [1, 2]. The disease is classified as either mild to moderate disease (with no or mild symptoms up to mild pneumonia), severe disease (with hypoxia, dyspnea or $>50 \%$ lung involvement on imaging within 48 hours), or critical illness (with respiratory failure, multiorgan dysfunction or shock) [3-6]. However, the vast majority (around 80 to $85 \%$ ) of infections result in a mild to moderate illness [7].

The ideal therapies for management of COVID-19 are still under investigation. Favipi-

*Corresponding Author: Farhat Abbas, Senior Resident, Pathology Division Government Medical College, Srinagar, 190011, India. E-mail: farahabbas.m@gmail.com ravir is an antiviral agent which has been previously used for treatment of influenza and was recently approved for treatment of mild to moderate COVID-19 in India [8, 9]. It has shown promise in an early non-randomized open label clinical trial in patients with non-severe disease, where use of Favipiravir was associated with faster rates of viral clearance (median time to clearance 4 versus 11 days) and more frequent radiographic improvement (in 91 versus 62 percent by day 14) compared with lopinavirritonavir [10]. Other robust studies are underway to assess the utility of Favipiravir in the management of COVID-19. We describe our early experience with the use of Favipiravir in patients with COVID-19.

\section{Methods}

A total of 17 patients were included in this observational study. The included patients were RT-PCR positive for SARS-CoV-2 with increased inflammatory markers. Clinical Characteristics 
of the patient population was studied. The inflammatory markers done in all patients were Interlekin-6, Ferritin, C-Reactive protein, Lactate dehydrogenase (LDH), D-Dimer. The other investigations done in all the included patients were Complete Blood count, Liver Function and Kidney Function tests, Urine examination, Blood Cultures, Serum procalcitonin. Ultrasound abdomen, Xray Chest and High-Resolution computed tomography Chest. All patients received Antiviral therapy, Anticoagulation (Enoxaparin $0.4 \mathrm{mg}$ SC twice daily), Steroids (Dexamethasone $8 \mathrm{mg}$ daily for 5 days and $4 \mathrm{mg}$ daily for 5 days). Viral clearance (time to RT-PCR negative), time to defervescence after antiviral therapy, time to become independent of Oxygen support and development of any complication during hospital stay was studied. Patients requiring mechanical ventilation at presentation to hospital were not included in this study.

\section{Results}

Out of 17 patients, there were 7 females and 10 male patients. The mean age of patients was $43.88 \pm 14.62$ and mean Body mass index (BMI) was $23.54 \pm 1.62 \mathrm{~kg} / \mathrm{m}^{2}$. All had high grade fever and myalgias, while $9(52.9 \%)$ patients had dry cough on presentation. 5 patients complained of sore throat and shortness of breath was seen in 9 patients (table 1).

There were 4 patients with known Diabetes mellitus and 3 of them were hypertensive as well. Rest of the patients did not have any underlying comorbidity. However, in two patients, who developed new onset hyperglycemia during steroid course, were found to have $\mathrm{Hba} 1 \mathrm{C}$ in Prediabetic range. Out of 17 patients, $11(64.7 \%)$ patients had bilateral ground glass opacities on CT chest while 6 had consolidation in addition to ground glass opacities. All of our patients had Absolute Lymphocyte count (ALC) below 1500 while 4 patients had severe lymphopenia (ALC $<1000$ cells). The inflammatory markers and biochemical parameters are shown in table 2.

Table 1. Clinical features of patient population

\begin{tabular}{|l|c|}
\hline \multicolumn{1}{|c|}{ Clinical feature } & $\mathrm{n}(\%)$ \\
\hline Fever & $17(100)$ \\
\hline Myalgia & $17(100)$ \\
\hline Cough & $9(52.9)$ \\
\hline Sore throat & $5(29.4)$ \\
\hline Vomiting & $2(11.7)$ \\
\hline Dyspnea & $9(52.9)$ \\
\hline Epigastric discomfort & $1(0.05)$ \\
\hline
\end{tabular}

Table 2. Biochemical parameters and inflammatory markers

\begin{tabular}{|l|c|}
\hline \multicolumn{1}{|c|}{ Parameter } & Mean \pm SD \\
\hline Hemoglobin $(\mathrm{g} / \mathrm{dL})$ & $13.08 \pm 1.83$ \\
\hline Platelet $(\mathrm{lac} / \mu \mathrm{L})$ & $3.4 \pm 0.71$ \\
\hline Ferritin $(\mu \mathrm{g} / \mathrm{L})$ & $615.41 \pm 307.03$ \\
\hline ALT $(\mathrm{IU} / \mathrm{L})$ & $111.5 \pm 35.7$ \\
\hline Absolute lymphocyte count & $1180 \pm 213.2$ \\
\hline Bilirubin $(\mathrm{mg} / \mathrm{dL})$ & $0.92 \pm 0.23$ \\
\hline Triglyceride $(\mathrm{mg} / \mathrm{dL})$ & $125.4 \pm 21.01$ \\
\hline D-Dimer $(\mathrm{ng} / \mu \mathrm{L})$ & $566.13 \pm 207.92$ \\
\hline LDH $(\mathrm{U} / \mathrm{L})$ & $615 \pm 187.06$ \\
\hline IL 6 $(\mathrm{pg} / \mu \mathrm{L})$ & $80.58 \pm 98.06$ \\
\hline
\end{tabular}

In our study, 10 patients had mild transaminitis before Favipiravir and 3 developed self-limiting transaminitis after Favipiravir, 4 had normal Liver function test throughout. Two patient had acute kidney injury (AKIN class 1) that resolved during hospital stay. Blood culture was sterile in all the patients and Serum procalcitonin was negative in all the patients. Nine patients required oxygen support. Among them 7 were on oxygen support via Nasal Canula and 2 patients required non-invasive ventilation (NIV) during hospital stay. Favipiravir was given at a dose of $1800 \mathrm{mg}$ twice on day 1 and subsequently $800 \mathrm{mg}$ twice daily from day $2-10$. In two patients, who required NIV Favipiravir was stopped, and these patients received Remdesivir for a total of 5 days. In patients who received Favipiravir only, the median time to RT-PCR negative, defervescence and oxygen independence was 8,3 and 6 days respectively. There was no thrombocytopenia, bleeding bacterial sepsis in our patient population. There was no mortality in our study population.

\section{Discussion}

The optimal management of patients with COVID-19 is rapidly evolving based on extensive ongoing research. Initial studies have suggested a clinical benefit with Remdesivir (antiviral agent) and a mortality benefit with the use of glucocorticoids. Remdesivir, a nucleotide analogue, has in vitro activity against SARS-CoV-2 [11]. Although more data from comparative, randomized trials are emerging $[12,13]$, available reports suggest there is likely some clinical benefit to Remdesivir prompting emergency use authorization by the FDA for severe COVID-19 in hospitalized children and adults [14]. Remdesivir needs to be administered intravenously and should be avoided in patients with transaminitis (ALT $\geq 5$ times normal) or in 
patients with an estimated glomerular filtration rate $(e G F R)<30 \mathrm{~mL} / \mathrm{min}$ per $1.73 \mathrm{~m}^{2}$. It should also not be coadministered with hydroxychloroquine or chloroquine due to potential drug interactions. The use of dexamethasone (oral or intravenous) provided a mortality benefit at 28 days in hospitalised patients with COVID-19 compared to usual care alone as per a preliminary report of the RECOVERY trial, a large randomized open-label study in the United Kingdom [15]. However, no benefit was reported among patients who did not require either oxygen or ventilatory support; with a statistically non-significant trend towards higher mortality (17.8 versus 14 percent, RR 1.19, 95\% CI 0.91 1.55). Also, there remain uncertainties in this preliminary report, as the baseline mortality rate in this report was higher than that from some other trials. Thus, the absolute mortality benefit in other settings may not be as high as observed in this trial. Additionally, adverse effects (including secondary infections) were not reported in the preliminary report. Another antiviral agent which is being investigated for its use in patients with COVID-19 is a purine nucleoside analogue, Favipiravir. It selectively inhibits RNA dependent RNA polymerase (RdRP), an enzyme needed for RNA viral replication within human cells, by getting incorporated instead of guanine and adenine [8]. The drug is converted into its active phosphorylated form intracellularly and subsequently is recognized as a substrate by the viral RdRP. The incorporation of a single molecule of the active form of Favipiravir terminates the elongation of viral RNA [8]. Favipiravir is known to have a broad spectrum of activity towards RNA viruses (like influenza, bunyavirus, arenavirus, flavivirus, and filoviruses causing hemorrhagic fever) including activity against oseltamivir- and zanamivir-resistant influenza viruses $[8,16]$. Wang et al studied the in vitro antiviral efficiency of several drugs including Favipiravir against SARS-CoV-2, reporting that Favipiravir reduced the viral infection, albeit at higher concentrations half-maximal effective concentration $(E C 50)=61.88 \mu \mathrm{M}$, half-cytotoxic concentration $(\mathrm{CC50})>400 \mu \mathrm{M}$, selectivity index $(\mathrm{SI})>6.46$ [11]. Pertinently, in a previous study evaluating the efficiency of Favipiravir against Ebola virus, even with a high EC50 value in Vero E6 cells of $67 \mu \mathrm{M}$, the antiviral agent demonstrated $100 \%$ in vivo effectiveness in protecting mice against Ebola virus; suggesting that further clinical studies could better evaluate the in vivo response of this antiviral nucleoside [17].
Early clinical studies of Favipiravir for COVID-19 have been promising. A non-randomized open-label study by Cai et al. reported a significant reduction in time taken for viral clearance in COVID-19 patients treated with Favipiravir compared to historical controls who had received lopinavir/ritonavir [10]. This study from China involved administration of Favipiravir (1600 mg orally twice daily on day 1 followed by $600 \mathrm{mg}$ orally twice daily on days 2-14) in patients with mild to moderate COVID-19. Patients $\geq 75$ years old, those having severe or critical COVID-19, chronic liver disease or end-stage renal disease were excluded from the study. In addition to a significant reduction $(p<0.001)$ in median time to viral clearance in the Favipiravir arm (4 days; IQR=2.5-9) compared with the historical lopinavir/ritonavir arm (11 days; IQR=8-13), the vast majority of patients $(91.4 \%)$ in the former group had radiographic improvement versus $62.2 \%$ in the latter group at 14 days. There was a significantly lower rate of adverse events in patients receiving Favipiravir (11.4\% versus 55.6\%; $P<0.01$ ). In our study those patients who received Favipiravir only, the median time to RT-PCR negative, defervescence and oxygen independence was 8,3 and 6 days respectively. Chen et al conducted a prospective multicenter randomized open label study comparing outcomes in adult COVID-19 patients after administration of Umifenovir versus Favipiravir in addition to conventional therapy [18]. In their preprint article, they report a statistically non-significant $(p=0.1396$, difference of recovery rate: $0.0954 ; 95 \%$ CI: -0.0305 to 0.2213 ) higher clinical recovery rate at Day 7 in the Favipiravir group (61.2\%) compared to the Umifenovir group (51.6\%). Also, the Favipiravir group had significantly shorter latencies to relief in pyrexia (difference: 1.70 days, $\mathrm{P}<0.0001$ ) and cough (difference: 1.75 days, $P<0.0001)$. They reported only mild and manageable side effects from the use of Favipiravir. Although there is a paucity of highgrade evidence for the effectiveness of Favipiravir in COVID-19, the in vitro activity and benefits seen in early studies strongly suggest the potential for using Favipiravir in SARS-CoV-2 infection. Our observational study demonstrated improvement in the majority of patients with COVID-19 with use of Favipiravir.

\section{Conclusions}

Ease of oral administration and a profile of mild adverse effects are advantages of Favipiravir. Further evidence from well-designed 
randomized controlled trials should enable clinicians to better understand the role of Favipiravir in the management of the ongoing coronavirus pandemic. Additional studies are needed to compare the efficiency of Favipiravir compared to Remdesivir.

\section{Conflicts of Interest}

Authors declare no conflict of interest. Funding

No funding was received for this study.

\section{Acknowledgements}

We would love to thank Dr. Summyia Farooq of Pathology Division GMC Srinagar for helping us during this study.

\section{Author Contributions}

Muzamil Latief, Obeid Shafi - conceptualization, methodology, formal analysis, writing original draft, writing - reviewing and editing; Muzamil Latief, Zhahid Hassan, Farhat Abbas data curation, writing - reviewing and editing; Muzamil Latief, Obeid Shafi, Farhat Abbas investigation, formal analysis.

\title{
ФАВIПІРАВІР ТА ДЕКСАМЕТАЗОН У ЛІКУВАННI SARS-COV2 IНФЕКЦІЇ (пілотне дослідження)
}

\author{
M. Latief', O. Shafi' ${ }^{2}$, Z. Hassan ${ }^{3}$, *F. Abbas ${ }^{4}$ \\ 1 - GANDHI MEDICAL COLLEGE AND HOSPITAL, HYDERABAD, INDIA \\ 2 - FLUSHING HOSPITAL MEDICAL CENTER NEW YORK, USA \\ 3 - GOVERNMENT MEDICAL COLLEGE, BARAMULLA, INDIA \\ 4 - PATHOLOGY DIVISION GOVERNMENT MEDICAL COLLEGE, SRINAGAR, INDIA
}

Вступ. Клінічна картина коронавірусної хвороби (COVID-19) варіює від легкого перебігу до тяжких проявів з поліорганною дисфункцією. Противірусний засіб фавіпіравір, який раніше застосовувався для лікування грипу, нещодавно був схвалений для лікування COVID-19 легкого та середнього ступеня тяжкості в Індії.

Мета. Завданням цього дослідження - оцінка ефективності фавіпіравіру та дексаметазону при COVID-19.

Методи. У пілотне дослідження було включено 17 пацієнтів, у яких були позитивні ПлР тести до SARS-CoV-2 та підвищені маркери запалення. Усі пацієнти отримували противірусну терапію, антикоагулянт (еноксапарин 0,4 мг підшкірно двічі на день), глюкокортикостероїди (дексаметазон 8 мг щодня протягом 5 днів та 4 мг щодня протягом 5 днів). Досліджувалися такі показники: тривалість перебігу хвороби до негативних результатів ПЛР тесту, час нормалізації температури на тлі противірусної терапії, швидкість відновлення самостійного дихання.

Результати. Лихоманка, міалгія, сухий кашель та задишка були найпоширенішими симптомами COVID-19. У всіх пацієнтів була лімфопенія. При проведенні комп'ютерної томографії грудної клітки, у 11 (64,7\%) пацієнтів було знайдено симптом «матового скла», тоді як у 6 спостерігалися і симптом «матового скла» і ущільнення. У двох пацієнтів, яким була потрібна неінвазивна вентиляція, фавіпіравір було відмінено, і ці пацієнти отримували ремдесевір протягом 5 днів. У пацієнтів, які отримували лише фавіпіравір, медіана часу до негативного значення ПЛР тесту, швидкість повернення температури до нормальної та швидкість відновлення самостійного дихання становила 8,3 та 6 днів відповідно.

Висновок. Наше пілотне дослідження продемонструвало тенденцію до покращення у більшості пацієнтів із COVID-19 при застосуванні фавіпіравіру. Головні обмеження - мала кількість спостережень, та необхідність проведення додаткових досліджень для порівняння ефективності фавіпіравіру та ремдесевіру .

КЛЮЧОВІ СЛОВА: SARS-CoV-2; фавіпіравір; ремдесевір; COVID-19.

Information about the authors

Muzamil Latief, DM Resident, Nephrology Division Gandhi Medical College and Hospital, Secunderabad, India

ORCID 0000-0002-2267-6322, e-mail: muzamillatief.b@gmail.com

Obeid Shafi, Chief Resident, Flushing Hospital Medical Center, New York, USA

ORCID 0000-0003-2669-199X, e-mail: obeidshafi@gmail.com

Zhahid Hassan, Consultant, Government Medical College, Baramulla, India

ORCID 0000-0003-3724-8387, e-mail: xahid6676@yahoo.co.in

Farhat Abbas, Senior Resident, Pathology Division Government Medical College, Srinagar, India

ORCID 0000-0003-1922-4752, email: farahabbas.m@gmail.com 


\section{References}

1. World Health Organization. Director-General's remarks at the media briefing on 2019-nCoV on 11 February 2020. Available at: https://www.who.int/dg/ speeches/detail/who-director-general-s-remarks-atthe-media-briefing-on-2019-ncov-on-11-february2020. Accessed July 28, 2020.

2. Wu F, Zhao S, Yu B, Chen YM, Wang W, Song ZG, et al. A new coronavirus associated with human respiratory disease in China. Nature. 2020 Mar;579 (7798):265-69.

DOI: https://doi.org/10.1038/s41586-020-2008-3

3. Bajema KL, Oster AM, McGovern OL, Lindstrom S, Stenger MR, Anderson TC, et al. Persons evaluated for 2019 novel Coronavirus - United States, January 2020. MMWR Morb Mortal Wkly Rep. 2020 Feb 14;69(6):166-70.

DOI: https://doi.org/10.15585/mmwr.mm6906e1

4. Wang D, Hu B, Hu C, Zhu F, Liu X, et al. Clinical characteristics of 138 hospitalized patients with 2019 novel Coronavirus-infected pneumonia in Wuhan, China. JAMA. 2020 Mar 17;323(11):1061-69.

DOI: https://doi.org/10.1001/jama.2020.1585

5. Liu K, Fang YY, Deng Y, Liu W, Wang MF, Ma JP, et al. Clinical characteristics of novel coronavirus cases in tertiary hospitals in Hubei Province. Chin Med J (Engl). 2020 May 5;133(9):1025-31.

DOI: https://doi.org/10.1097/CM9. 0000000000000744

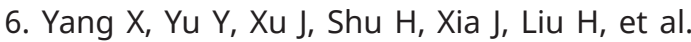
Clinical course and outcomes of critically ill patients with SARS-CoV-2 pneumonia in Wuhan, China: a single-centered, retrospective, observational study. Lancet Respir Med. 2020 May;8(5):475-481.

DOI: https://doi.org/10.1016/S22132600(20)30079-5

7. Wu Z, McGoogan JM. Characteristics of and important lessons from the Coronavirus Disease 2019 (COVID-19) outbreak in China: summary of a report of 72314 cases from the Chinese Center for Disease Control and Prevention. JAMA. $2020 \mathrm{Apr}$ 7;323(13):1239-42.

DOI: https://doi.org/10.1001/jama.2020.2648

8. Furuta Y, Komeno T, Nakamura T. Favipiravir (T-705), a broad spectrum inhibitor of viral RNA polymerase. Proc Jpn Acad Ser B Phys Biol Sci. 2017;93(7):449-63.

DOI: https://doi.org/10.2183/pjab.93.027

9. Glenmark becomes the first pharmaceutical company in India to receive regulatory approval for oral antiviral Favipiravir, for the treatment of mild to moderate COVID-19. Glenmark Pharmaceuticals Ltd.
Press release on 20 June 2020. Available at: https:// www.glenmarkpharma.com/sites/default/files/ Glenmark-becomes-the-first-pharmaceut-cal-company-in-India-to-receive.pdf. Accessed July 28, 2020.

10. Cai Q, Yang M, Liu D, Chen J, Shu D, Xia J, et al. Experimental treatment with favipiravir for COVID-19: an open-label control study. Engineering (Beijing). 2020 Oct;6(10):1192-98.

DOI: https://doi.org/10.1016/j.eng.2020.03.007

11. Wang M, Cao R, Zhang L, Yang X, Liu J, Xu M, et al. Remdesivir and chloroquine effectively inhibit the recently emerged novel coronavirus (2019-nCoV) in vitro. Cell Res. 2020 Mar;30(3):269-271

DOI: https://doi.org/10.1038/s41422-020-0282-0

12. Beigel JH, Tomashek KM, Dodd LE. Remdesivir for the Treatment of Covid-19 - Preliminary Report. Reply. N Engl J Med. 2020 Sep 3;383(10):994.

DOI: https://doi.org/10.1056/NEJMoa2007764

13. Wang Y, Zhang D, Du G, Du R, Zhao J, Jin Y, et al. Remdesivir in adults with severe COVID-19: a randomised, double-blind, placebo-controlled, multicentre trial. Lancet. 2020 May 16;395(10236):1569-78.

DOI: https://doi.org/10.1016/S0140-6736(20) 31022-9

14. Remdesivir letter of EUA. US FDA. Available at: https://www.fda.gov/media/137564/download. Accessed on: July 22, 2020.

15. RECOVERY Collaborative Group, Horby $P$, Lim WS, Emberson JR, Mafham M, Bell JL, Linsell L, et al. Dexamethasone in Hospitalized Patients with Covid-19. N Engl J Med. 2021 Feb 25;384(8):693-704

DOI: https://doi.org/10.1056/NEJMoa2021436

16. Shiraki K, Daikoku T. Favipiravir, an antiinfluenza drug against life-threatening RNA virus infections. Pharmacol Ther. 2020;209:107512.

DOI: https://doi.org/10.1016/j.pharmthera. 2020.107512

17. Oestereich L, Lüdtke A, Wurr S, Rieger T, Muñoz-Fontela C, Günther S. Successful treatment of advanced Ebola virus infection with T-705 (favipiravir) in a small animal model. Antiviral Res. 2014;105:17-21.

DOI: https://doi.org/10.1016/j.antiviral.2014.

18. Chen C, Zhang Y, Huang J, et al. Favipiravir versus Arbidol for COVID-19: A Randomized Clinical Trial. medRxiv; 2020.

DOI: https://doi.org/10.1101/2020.03.17. 20037432

Received 31 Oct 2020; revised 17 Dec 2020; accepted 24 Dec 2020.

This is open access article distributed under the Creative Commons Attribution License, which permits unrestricted use, distribution, and reproduction in any medium, provided the original work is properly cited. 